\title{
IZGRADNJA RAZNOLIKIH \\ FILMSKIH ZBIRKI U NARODNIM KNJIŽNICAMA
}

\author{
DEVELOPMENT OF DIVERSE FILM \\ COLLECTIONS IN PUBLIC LIBRARIES
}

\author{
Mirko Duić \\ Odjel za informacijske znanosti \\ Sveučilište u Zadru \\ miduic@unizd.hr
}

UDK / UDC 791.43:[02:655-051]

Izvorni znanstveni rad / Original scientific paper

Prihvaćeno / Accepted: 25.4.2017.

\section{Sažetak}

U radu su istražena razmišljanja, iskustva i stavovi knjižničara koji rade s filmskom građom u hrvatskim narodnim knjižnicama, kao i razmišljanja, iskustva i stavovi hrvatskih filmskih nakladnika te su istraženi načini suradnje filmskih nakladnika i knjižničara. Fokus istraživanja usmjeren je na raznolikost filmova u hrvatskim narodnim knjižnicama. Podaci su prikupljeni kvalitativnom metodom polustrukturiranog intervjua. Istraživanjem je utvrđeno da je temeljna poteškoća u izgradnji raznolikih filmskih zbirki nedostatak raznolike ponude filmova na hrvatskom tržištu. Razmotrene su različite knjižnične aktivnosti koje mogu unaprijediti raznolikost filmskih zbirki. U Hrvatskoj do sada nije bilo sličnih istraživanja, pa ovaj rad može biti i poticaj za njihovu provedbu.

Ključne riječi: narodne knjižnice, filmski nakladnici, filmske zbirke, raznolikost, film

\section{Summary}

The paper provides an exploration of the reflections, experiences, and attitudes of the librarians who work with film materials in Croatian public libraries. The paper also

Vjesnik bibliotekara Hrvatske 60, 2-3(2017), 111-135

ISSN 0507-1925

(C) VBH 2017. 
presents an exploration of the reflections, experiences, and attitudes of the Croatian film publishers, as well as the ways of cooperation between the film publishers and the librarians. The focus of the research was directed at the film diversity in Croatian public libraries. The data were collected with the qualitative method of a structured interview. The results confirmed that the basic problem in the development of diverse film collections is the lack of diverse film supply at the Croatian market. Various library activities that could enhance the diversity of film collections were also considered. Since there have not been similar studies in Croatia before, this study could serve as an incentive for such future studies.

Keywords: public libraries, film publishers, film collections, diversity, film

\section{Uvod}

U IFLA-inim ${ }^{1}$ Smjernicama za audiovizualnu i multimedijsku građu u knjižnicama i drugim ustanovama objavljenim 2005. godine navodi se da je još 1972. godine u UNESCO-ovu Manifestu za narodne knjižnice istaknuta potreba za audiovizualnom građom u narodnim knjižnicama, kako na odjelima za odrasle tako i na odjelima za djecu. ${ }^{2}$ U Smjernicama se ističe da su audiovizualni mediji ${ }^{3}$ dio kulturnog nasljeđa čovječanstva, da sadrže veliku količinu informacija koju treba sačuvati te da se raznolikost medija u društvu treba odražavati u uslugama koje knjižnice nude svojim korisnicima. ${ }^{4}$ Autori Smjernica mišljenja su da korisnicima audiovizualne i multimedijske građe treba pružiti istu razinu usluga kao i korisnicima tiskane građe, a knjižnično osoblje mora razumjeti komplementarnost tih zbirki kako bi korisnicima moglo dati pouzdanu i potpunu informaciju. Jedna od prednosti audiovizualne građe jest to što „može privući sve one koji se ne mogu ili ne žele služiti tiskanom građom, odnosno one koji ne žele čitati ili pak one koji imaju poteškoće s vidom“. ${ }^{5}$ Također, značajno je da se u dokumentu Američkog knjižničnog društva (American Library Association ili ALA) The freedom to view statement iz 1990. godine gledanje kao ustavno pravo izjednačuje s govorenjem, slušanjem i čitanjem. U tom se tekstu ohrabruje knjižnice da osiguraju najširi mogući pristup filmu, videu i drugoj audiovizualnoj građi kojom se komuniciraju

1 IFLA - International Federation of Library Associations and Institutions (Međunarodna federacija knjižničnih udruženja i institucija).

2 Vidi IFLA. Smjernice za audiovizualnu i multimedijsku građu u knjižnicama i drugim ustanovama, 2005. Str. 7. [citirano: 2017-09-17]. Dostupno na http://archive.ifla.org/VII/s35/pubs/ avm-guidelines04-hr.pdf.

3 Pojam audiovizualni mediji ili audiovizualna građa koristi se u Smjernicama u kontekstu zbirki svih vrsta knjižničnih i informacijskih usluga koje se odnose na zvuk, pokretne i nepokretne slike.

4 Isto, str. 8.

5 Isto, str. 18. 
ideje. ${ }^{6}$ Mnoge hrvatske narodne knjižnice izgradile su filmske zbirke. Međutim u uvjetima tržišne ekonomije i dominacije motiva profita unutar prostora kulture postavlja se pitanje mogu li i kako javne institucije poput knjižnica ponuditi svojim korisnicima raznolike i bogate filmske zbirke i tako ostvariti jedan od svojih ključnih ciljeva. Na važnost osiguravanja raznolikih vrijednih djela u knjižnici, bilo da se radi o knjigama, filmovima, glazbi ili nekim drugim dokumentima, ukazuju misije i ciljevi koje imaju. Također brojni autori ukazuju na važnost osiguravanja raznolikih vrijednih djela u knjižnici. Naprimjer T. Aparac-Jelušić smatra da kvaliteta knjižnice ovisi i o tome u kojoj mjeri ona osigurava pristup svim relevantnim svjetskim kulturnim izvorima. ${ }^{7} \mathrm{~K}$. Lojo smatra da je svrha knjižničarstva svim zainteresiranim korisnicima omogućiti pristup dokumentarnom naslijeđu i informacijskim izvorima kojima raspolaže knjižnica. ${ }^{8} \mathrm{C}$. Grant navodi citat iz knjige Practical administration of public libraries:

„The library's functions and programs derive from the conviction that books and other printed material, as well as audiovisual materials are a powerful, indispensible agent for bringing enlightenment, new knowledge, encouragement and inspiration to every member of the community. ... the quickest and easiest access to the world's best thought is through the public library." 9

Prema navedenom citatu, knjižnični programi i usluge proizlaze iz uvjerenja da su knjige, filmovi i drugi tipovi dokumenata nezaobilazni za stjecanje novih znanja, prosvjećivanje i inspiraciju svih članova određene zajednice. Stoga je korištenje narodnih knjižnica najjednostavniji i najbrži način za stjecanje uvida o najvrednijim mislima iz cijelog svijeta.

Međutim u izgradnji raznolikih knjižničnih zbirki nailazi se na različite poteškoće. Jedan od problema nastaje kada na tržištu nema raznolikih i vrijednih filmova ili drugih tipova građe jer nakladnici odlučuju objavljivati samo najpopularnija, odnosno najprofitnija djela. U vezi s time može se govoriti o ekonomskoj cenzuri koju N. Kranich definira kao cenzuru kod koje nakladnici odbijaju nove autore i kritična motrišta iz straha da se neprovjereni i kritični naslovi i autori neće dovoljno dobro prodavati. Stoga Kranich upozorava na to da knjižnice ne

\footnotetext{
6 Vidi ALA. The freedom to view statement, 1989. [citirano: 2017-09-17]. Dostupno na http:// www.ala.org/vrt/professionalresources/vrtresources/freedomtoview.

7 Vidi Aparac, Tatjana. Biti bibliotekar: jučer, danas, sutra. // Knjižnica: glasilo Zveze bibliotekarskih društev Slovenije 41, 2(1997), str. 38-39.

8 Vidi Lojo, Kemal. Bibliotekarstvo između profesionalizacije i ideologizacije. // ICSL Godišnjak, 6-7(2011), 195.

9 Wheeler, Joseph L.; Herbert Goldhor. Practical administration of public libraries. New York: Harper \& Row, 1966. Citirano prema: Grant, Carl Value-added librarianship: creating it in our services and in the infrastructure upon which we rely. // Public Library Quarterly 32, 1(2013), str. 23.
} 
mogu graditi uravnotežene zbirke bez znatnog ulaganja u alternativne izvore koji postoje nasuprot najvećim nakladnicima. ${ }^{10} \mathrm{~J}$. Buschman upozorava na to da su knjižnice, baš kao i sveučilišta i škole, ugrožene interesima organizacija orijentiranih na zaradu. Smatra da su knjižnice u demokratskim sustavima važan gradivni dio javne sfere jer one organiziranjem zbirki prema načelu slobodnog pristupa informacijama omogućuju i razvijaju racionalni diskurs. Ističe da knjižničarstvo njeguje načelo kritične i racionalne argumentacije kroz posvećenost izgradnji raznolikih i uravnoteženih zbirki koje odražavaju povijesnu i trenutnu intelektualnu raznolikost. ${ }^{11}$ Problem na koji ukazuje Buschman, a koji otežava izgradnju takvih zbirki, jest to što smo postali neuravnoteženo društvo jer ekonomski način razmišljanja o društvu i njegovim problemima dominira javnom filozofijom. ${ }^{12}$

\section{Okrupnjivanje nakladnika i utjecaj na izgradnju knjižničnih zbirki}

Jedna od bitnih poteškoća u izgradnji knjižničnih zbirki može biti okrupnjivanje nakladnika. K. Schmidt ističe da su nakladnička okrupnjivanja ponekad imala katastrofalan učinak na knjižnične zbirke i proračune. Velike nakladničke korporacije nameću cijene i monopoliziraju objavljivanje u određenim područjima. Kao poseban izazov za knjižnične zbirke ističe poteškoće u pronalaženju novca i vremena za nabavu knjižnične građe od malih nezavisnih nakladnika. ${ }^{13} \mathrm{P}$. McDonald smatra da fokus rasprave o cenzuri treba biti na korporativnoj hegemoniji koja sustavno umanjuje slobodno umjetničko i kulturno izražavanje te ometa pristup informacijama, a samim time i knjižničarstvo. Kao glavne uzroke zbog kojih nakladničke korporacije guše slobodno kretanje neuobičajenih ideja navodi strah da se djelo neće dobro prodavati te samozaštitu i strah od kontroverznih pitanja. No bez slobodnog kretanja informacija demokratska rasprava građana ometena je od samog početka. U lakom prihvaćanju statusa quo McDonald prepoznaje pogubnu korporacijsku dominaciju koja ima potencijal ,umrtviti samu dušu naše profesije“..$^{14}$

10 Vidi Kranich, Nancy. A question of balance: the role of libraries in providing alternatives to the mainstream media. // Collection Building, 19, 3(2000), str. 85-91. Citirano prema: Lilburn, Jeff. Too much "official" truth? Mainstream media, the alternative Press and the construction of common knowledge. SIMILE: Studies in Media \& Information Literacy Education 5, 4(2005), str. 7.

11 Vidi Buschman, John. On libraries and the public sphere. // Library Philosophy and Practice 7, 2(2005), str. 2.

12 Isto, str. 6.

13 Vidi Schmidt, Karen. Past perfect, future tense: a survey of issues in collection development. // Library Collections, Acquisitions, \& Technical Services 28, 4(2004), str. 365.

14 Vidi McDonald, Peter. Corporate inroads \& librarianship: the fight for the soul of the profession in the new millenium. // Progressive Librarian, 12-13(1997), str. 33. 
Okrupnjivanje nakladnika na globalnoj razini prisutno je u različitim granama kulturne industrije, bilo da se radi o knjigama, filmovima ili glazbi. Znakovit je podatak da je do 2006. godine manje od deset korporacija, od kojih je većina iz SAD-a, imalo u vlasništvu većinu svjetskih medijskih industrija. ${ }^{15}$ Procese okrupnjivanja i korporacijske sinergije osvjetljavaju i razmišljanja J. Habermasa o kulturnoj homogenizaciji svijeta. Habermas smatra da se putem globalnog tržišta, masovne potrošnje i komunikacije širom svijeta plasiraju standardizirani proizvodi masovne culture, npr. isti filmovi i televizijski programi, iste knjige $\mathrm{i}$ glazba privlače i oblikuju mentalitet mladih ljudi bez obzira u kojem dijelu svijeta se nalazili. ${ }^{16}$

Iako nakladničko okrupnjivanje može imati vrlo nepovoljne posljedice po raznolikost ponude i mogućnost izgradnje raznolikih knjižničnih zbirki, nema puno istraživanja o tom problemu. Među znanstvenicima koji proučavaju tu temu vrijedi istaknuti J. Dilevka koji je zajedno s različitim drugim autorima objavio niz s time povezanih istraživanja. ${ }^{17}$ Također, o okrupnjivanju nakladnika i prijetnjama raznolikosti knjižničnih zbirki i aktivnosti detaljno govori tekst Američkog knjižničnog udruženja u kojem se ističe da knjižnice ne smiju ovisiti o tradicionalnim pasivnim pristupima nabavi, već moraju biti agilne i samopouzdane u traženju alternativnih glasova. Razlog je u tome što glavni mediji sve više okrupnjuju, dok su alternativni glasovi sve neprimjetniji. U tekstu se ističe da knjižnice trebaju preuzeti aktivnu ulogu ako žele osigurati pristup širokom rasponu ideja. U suprotnom će se odreći svoje odgovornosti osiguravanja slobodnog izražavanja i promicanja javnog interesa u digitalnom dobu. Neke od aktivnosti koje se u tom tekstu preporučuju knjižničarima kako bi izgrađivali raznolike i kvalitetne zbirke jesu: pripremiti politiku odabira djela i izgradnje zbirki koja ističe važnost raznolikih zbirki knjižnične građe; promicati raznolikost informacijskih izvora i različitih motrišta ključnih za informirano građanstvo; odrediti knjižničare koji će pratiti male i nezavisne nakladnike i pružati preporuke za izgradnju zbirke; obrazovati zaposlenike o važnosti uključivanja alternativnih izvora informacija u zbirke. ${ }^{18}$

15 Usp. Thussu, Kishan Daya. News as entertainment: the rise of global infotainment. Thousand Oaks, Calif. : Sage, 2007. Str. 49.

16 Usp. Habermas, Jürgen. The postnational constellation: Political essays. Cambridge, MA: MIT Press, 2001. Str. 75.

17 Dilevko, Juris; Kalina Grewal. New approach to collection bias in academic libraries: The extent of corporate control in journal holdings. // Library \& Information Science Research 19, 4(1997), str. 359-385; Dilevko, Juris.; Alison Hayman. Collection development patterns of fiction titles in public libraries: the place of independent and small presses. // Library \& Information Science Research 22, 1(2000), str. 35-59; Dilevko, Juris. An alternative vision of librarianship: James Danky and the sociocultural politics of collection development. // Library Trends 56, 3(2008), str. 678-704.

18 ALA. Intellectual Freedom Committee Subcommittee on the Impact of Media Concentration on Libraries. Fostering media diversity in libraries - strategies and actions. // Intellectual Free- 
Još jedan aspekt vrlo je bitan za izgradnju filmskih zbirki. Radi se o aspektu neutralnosti knjižnica. U kontekstu izgradnje raznolikih filmskih zbirki pitanje neutralnosti bitno je jer određuje načine na koje se knjižnice tj. knjižničari postavljaju prema nepovoljnim komercijalnim utjecajima i neraznolikosti filmske ponude na tržištu. M. K. Buckland istraživanje neutralnosti smatra jednim od pet velikih izazova knjižničnih istraživanja, $\mathrm{i}$ to upravo $u$ kontekstu kontinuiranog okrupnjivanja medijskih nakladnika u nekoliko ogromnih korporacija. ${ }^{19}$ Imajući na umu misiju knjižnica da osiguraju pristup raznolikoj građi, Buckland postavlja pitanje na koji način knjižničari mogu imati učinkovit utjecaj, s obzirom na snažnu ulogu nakladnika. J. Hansson podsjeća da je ideja neutralne knjižnice promicana od samih početaka narodnog knjižničarstva sredinom 19. stoljeća. Prema Hanssonu osnovna misija narodne knjižnice jest to da bude svojevrsno društveno ogledalo, tako što će putem svojih zbirki, izložbi ili predavanja predstavljati najraznovrsnija mišljenja prisutna u društvu. ${ }^{20}$ To razmišljanje u skladu je s mišljenjem da su temeljni elementi neutralne knjižnice zbirke knjiga, filmova i drugih tipova građe koje odražavaju društvenu raznolikost. No da bi se izgradile raznolike zbirke filmova ili raznolike knjižnične zbirke bilo koje druge vrste građe, nužno je da knjižničari sustavno osmišljavaju i provode različite inovativne aktivnosti.

\section{Raznolikost filmske ponude u Hrvatskoj}

Raznolikost filmske ponude u različitim neknjižničnim medijskim i distribucijskim kanalima bitan je čimbenik koji utječe na izgradnju i korištenje knjižničnih filmskih zbirki. Ako su izvan knjižnice pretežno dostupni određeni tipovi filmova, tj. ako je ponuda filmova neraznolika, tada će mnogo korisnika knjižnica izvan knjižnice razvijati sklonost prema najdostupnijim filmovima te će i u knjižnici tražiti ponajprije tipove filmova na koje su naviknuti u ostalim medijima. Stoga je poznavanje ponude filmova izvan knjižnice vrlo važno za orijentiranje i usmjeravanje aktivnosti knjižničara koji rade s filmovima. No osim toga što nema istraživanja o raznolikosti filmske ponude u hrvatskim narodnim knjižnicama, gotovo uopće nema ni istraživanja o raznolikosti filmske ponude izvan knjižnica. Jedno od vrlo rijetkih istraživanja jest izvještaj o stanju hrvatske kinematografije iz 2001. godine. Autori izvještaja navode da se na HRT-u emitira velik broj igranih filmova, od kojih je $65 \%$ do $70 \%$ igranih filmova iz SAD-a, $20 \%$ do $25 \%$ igranih filmova iz europ-

\footnotetext{
dom Manual. Chicago: American Library Association, 2010. Str. 12.

19 Vidi Buckland, Michael K. Five grand challenges for library research. // Library Trends 51, 4(2003), str. 682.

20 Usp. Hansson, Joacim. Chantal Mouffe's theory of agonistic pluralism and its relevance for library and information science research. // Critical theory in library and information science: exploring the social from across the disciplines / ed. by John. E. Buschman, Lisa M. Given and Gloria J. Leckie. Santa Barbara, Calif. : ABC-CLIO, 2010. Str. 255.
} 
skih država, a ostali su igrani filmovi iz drugih izvaneuropskih država. Hrvatskih igranih filmova prikazuje se tek oko $2 \%{ }^{21}$ Iz tih je podataka vidljivo da situacija po pitanju raznolikosti emitiranih filmova nije povoljna. Prema istom izvještaju kinorepertoarom domaćih komercijalnih kina dominirali su filmovi iz SAD-a (74 \% do $85 \%$ repertoara). Ostatak su pretežno činili europski filmovi, a prikazan je tek poneki izvaneuropski film. Također, kinorepertoarom su dominirali recentni filmovi, uglavnom snimljeni u posljednje tri godine. ${ }^{22} \mathrm{Za}$ distribuciju igranih filmova ističu da je isključivo komercijalno usmjerena i da se distributeri pretežno vezuju uz velike američke filmske distribucijske tvrtke. ${ }^{23}$ Distribucija nekomercijalnih i kratkih filmskih formi vrlo je ograničena i ozbiljno otežana. ${ }^{24} \mathrm{Na}$ nedostupnost domaćih filmova ukazuje i J. Pavičić istaknuvši primjer redatelja Branka Bauera koji je vlastite filmove morao ići gledati na retrospektivu hrvatskog filma u Nizozemskoj jer se u Hrvatskoj nemaju gdje vidjeti. Također ističe da filmski povjesničari, kritičari i filmolozi putuju već drugu godinu u Trst na Alpe Adria Cinema, festival filma srednje i istočne Europe, kako bi „mogli gledati stari hrvatski film: jer, njega u kinotekama nema (ima li kinoteka?!), a na televiziji se tek stidljivo izborio za termin ponedjeljkom navečer". ${ }^{25}$

Ako u različitim neknjižničnim medijima u Hrvatskoj postoji problem s ponudom raznolikih filmova, može se postaviti pitanje u kojoj su mjeri raznolike filmske zbirke hrvatskih narodnih knjižnica. Ako filmski nakladnici na DVD-diskovima, na kojima je pohranjena većina filmova u knjižnicama, objavljuju pretežno filmove koji im donose najveći profit, onda će raznolikost filmova dostupnih na domaćem tržištu biti malena. Upravo je stanje neraznolikosti filmske ponude pružilo važan poticaj za izradu ovoga rada. U vezi s time zanimljiva je usporedba knjiškog i filmskog nakladništva. U Hrvatskoj se mjerama kulturne politike znatno unaprijedila dostupnost i raznolikost prevedenih knjiga. $U$ tom smislu vrlo su značajne potpore za objavljivanje knjiga koju već dulji niz godina knjiškim nakladnicima dodjeljuje Ministarstvo kulture. Naprimjer u Javnom pozivu za dodjelu potpora za izdavanje knjiga u 2014. godini navedeno je da su u proračunu Ministarstva kulture za književno izdavaštvo osigurana sredstva u iznosu do sedam milijuna kuna. U Pozivu također piše da će Ministarstvo dodjeljivati potporu za objavljivanje novih domaćih knjiga, kao i prijevoda stranih djela koja su opća kulturna dostignuća. ${ }^{26} \mathrm{Na}$ taj tip natječaja mogle su se kao nakladnici prijavljivati

21 Vidi Majcen, Vjekoslav; Hrvoje Turković. Kinematografija u Hrvatskoj - izvještaj o stanju. // Hrvatski filmski ljetopis 7, 27(2001), str. 70.

22 Isto, str. 69.

23 Isto, str. 68.

24 Isto, str. 55.

25 Vidi Pavičić, Jurica. Po hrvatski film u Trst. // Hrvatski filmski ljetopis 5, 17 (1999), str. 41.

26 Vidi Ministarstvo kulture. Javni poziv za dodjelu potpora za izdavanje knjiga u 2014. godini. Str. 3. [citirano:2017-09-17]. Dostupno na http://www.min-kulture.hr/userdocsimages/Natjecaji/ 
i knjižnice. ${ }^{27}$ Jasno je da tako obilna financijska potpora od strane Ministarstva nakladnicima omogućuje objavljivanje mnogo vrijednih i raznolikih knjiga koje inače možda nikada ne bi imali interesa objaviti. Međutim u Hrvatskoj ne postoji ni približno jednaka financijska državna potpora za objavljivanje vrijednih filmova na DVD-diskovima. Stoga je ponuda tih filmova prepuštena tržišnim zakonitostima, a to u situaciji gdje ima zaista malo filmskih nakladnika može dovesti do toga da u ponudi prevladavaju najpopularniji filmovi koji su prvenstveno usmjereni na zabavu gledatelja, dakle igrani filmovi holivudske kinematografije. Filmovi iz drugih država, a posebno dokumentarni i animirani filmovi, stariji filmovi i filmovi iz SAD-a koji nisu nastali u okviru holivudske kinematografije, tada neće biti u znatnoj mjeri objavljivani na DVD-diskovima jer zbog svoje nepoznatosti kod gledatelja nakladnicima nisu dovoljno isplativi. Ako je ponuda filmova na tržištu neraznolika, onda ni knjižnice ne mogu imati raznolike filmske zbirke. Iako filmske zbirke mogu biti relativno velike u knjižnicama koje imaju dovoljno financijskih sredstava, one će se zbog neraznolikosti filmova na tržištu pretežno sastojati od popularnih novijih holivudskih igranih filmova. U ovome radu istražujemo različite aspekte bitne za izgradnju filmskih zbirki, a zbog opisane nepovoljne situacije neraznolikosti ponude filmova u Hrvatskoj fokus je istraživanja na razmišljanjima, iskustvima i stavovima knjižničara i nakladnika o stanju raznolikosti filmske ponude na tržištu i u knjižničnim filmskim zbirkama. Rad je nastao na temelju doktorskog rada Filmske zbirke u hrvatskim narodnim knjižnicama autora Mirka Duića, izrađenog na Sveučilištu u Zadru pod mentorskim vodstvom prof. Tatjane Aparac-Jelušić. ${ }^{28} \mathrm{U}$ ovome se članku predstavlja jedan dio provedenih istraživanja.

\section{Istraživanje}

\subsection{Metodologija istraživanja}

\section{Intervjui s knjižničarima}

Da bismo istražili razmišljanja, iskustva i stavove knjižničara o izgradnji filmskih zbirki, intervjuirali smo metodom polustrukturiranog intervjua knjižničare koji rade u multimedijskim zbirkama 18 narodnih knjižnica u Hrvatskoj. Intervjui su provedeni u razdoblju od 10. do 23. prosinca 2014. godine. U svakoj knjižnici intervjuirana je osoba odgovorna za rad s filmovima, osim u jednoj knjižnici, u kojoj je proveden grupni intervju u kojem su sudjelovale četiri osobe čiji je rad

natje \%C4\%8Daj\%20programa\%20knji\%C5\%BEevne, $\% 20$ nakladni $\%$ C4\%8Dke\%20i\%20knji\%C5\%BEarske/Upute_potpore_dopunjeno\%20(2)_LEKT.pdf.

27 Isto, str. 5.

28 Duić, Mirko. Filmske zbirke u hrvatskim narodnim knjižnicama. Doktorska disertacija. Zadar : Sveučilište u Zadru, 2015. 
povezan s filmskom građom. Intervjui su anonimni. Pojedine knjižnice u ovom radu označene su šiframa od K1 do K18. Takav pristup odabran je kako bi knjižničari otvorenije i detaljnije pričali o određenim temama. S druge strane, nedostatak navedenog pristupa jest to što bi neki odgovori bili informativniji za čitatelje kada bi znali na koju se knjižnicu odgovor odnosi - svaka knjižnica ima svoje specifičnosti koje mogu utjecati na razumijevanje i interpretaciju odgovora.

Pri izradi uzorka nastojalo se da budu zastupljene knjižnice iz različitih hrvatskih regija. U Zagrebu i Splitu, velikim gradovima s većim gradskim mrežama knjižnica, proveli smo intervjue u središnjim knjižnicama i u njihovim ograncima u kojima se nalazi veći broj filmova. Intervjui su provedeni u sljedećim gradovima i knjižnicama: Benkovac (Gradska knjižnica Benkovac), Osijek (Gradska i sveučilišna knjižnica Osijek), Solin (Gradska knjižnica Solin), Split (Gradska knjižnica Marka Marulića: Središnja knjižnica, Knjižnica Brodarica, Knjižnica Ravne njive), Šibenik (Gradska knjižnica „Juraj Šižgorić“ Šibenik), Rijeka (Gradska knjižnica Rijeka), Zadar (Gradska knjižnica Zadar), Zagreb (Knjižnice grada Zagreba: Gradska knjižnica - Informativno-posudbeni odjel, Gradska knjižnica - Medioteka, Knjižnica Tina Ujevića, Knjižnica Dugave, Knjižnica Dubrava, Knjižnica Augusta Cesarca, Knjižnica Silvija Strahimira Kranjčevića, Knjižnica Špansko-sjever), Zaprešić (Knjižnice grada Zagreba: Gradska knjižnica Ante Kovačića).

Tijekom intervjua su se, ovisno o odgovorima ispitanika i specifičnostima filmskih zbirki u pojedinoj knjižnici, postavljala dodatna pitanja kako bi se odgovori dodatno pojasnili. Pri oblikovanju pitanja koristili smo spoznaje iz literature o metodologiji izrade pitanja za intervjue. ${ }^{29}$ Svim knjižničarima obuhvaćenim istraživanjem pitanja su unaprijed poslana kako bi bili upoznati s temama koje će se istražiti intervjuom.

U intervjuima su istražene sljedeće teme vezane uz izgradnju i raznolikost filmskih zbirki: poteškoće u radu vezanom uz filmske zbirke; ocjena kvalitete knjižnične filmske zbirke; mogućnosti za razvoj kvalitetnijih filmskih zbirki; najviše i najmanje posuđivani tipovi filmova; filmski interesi različitih skupina korisnika; kriteriji koji su knjižničarima bitni pri odabiru filmova za zbirku; načini nabave filmova za knjižnicu; razina zadovoljstva ponudom filmova na DVD-diskovima na domaćem tržištu; povećava li se ponuda filmova ili se smanjuje; mogućnosti unapređenja suradnje i procesa nabave; nabava filmova od inozemnih dobavljača; dostupnost u knjižničnoj zbirci stranih filmova neprevedenih na hrvatski; stajališta o mogućnosti da se knjižnice uključe kao nakladnici u objavljivanje na DVD-diskovima vrijednih domaćih i stranih prevedenih filmova.

29 Evans, Edward G.; Margaret Zarnosky Saponaro. Developing library and information center collections. Westport, Conn. : Libraries Unlimited, 2005.; Wilson, Virginia. Research methods: interviews. // Evidence Based Library and Information Practice 7, 2 (2012), str. 96-97. 


\section{Intervjui s nakladnicima}

Da bismo istražili razmišljanja, iskustva i stavove nakladnika o suradnji s knjižnicama te ponudi i tržištu filmske građe, proveli smo polustrukturirane intervjue s hrvatskim filmskim nakladnicima. Intervjui su provedeni s trima filmskim nakladnicima u razdoblju od 20. do 23. veljače 2015. godine. Intervjuirane su osobe odgovorne za objavljivanje filmova. Dva su nakladnika velike nakladničke tvrtke - Menart ${ }^{30}$ i Discovery ${ }^{31}$. U istraživanje smo uključili i nakladnika Restart labe $^{32}$ koji objavljuje manji broj recentnih dokumentarnih filmova. Sva tri nakladnika imaju sjedište u Zagrebu. Važno je ukazati na činjenicu da u Hrvatskoj gotovo i nema drugih većih nakladnika filmova na DVD-diskovima. ${ }^{33}$

Tijekom intervjua su se, ovisno o odgovorima ispitanika i specifičnostima nakladnika, postavljala dodatna pitanja kako bi se odgovori pojasnili. Pri oblikovanju pitanja koristili smo spoznaje iz literature o metodologiji izrade pitanja za intervjue. ${ }^{34}$ Svim nakladnicima obuhvaćenim istraživanjem pitanja su unaprijed poslana kako bi bili upoznati s temom intervjua.

Intervju je bio podijeljen u sljedeće tri tematske skupine: stanje tržišta filmova na DVD-diskovima u Hrvatskoj; objavljivanje filmova na DVD-diskovima; poslovanje pojedinog nakladnika s knjižnicama. Bitno je napomenuti da se uvidi iz intervjua ne mogu u potpunosti generalizirati jer različiti nakladnici djeluju u različitim okolnostima i imaju različite ciljeve. Također, bitno je istaknuti da smo u ovom istraživanju intervjuirali tek tri nakladnika, no s obzirom na to da na hrvatskom tržištu nema većeg broja značajnijih nakladnika, na osnovi intervjua $\mathrm{s}$ ta tri nakladnika nastojali smo oblikovati tvrdnje za koje smatramo da pružaju, ako već ne sveobuhvatnu, onda prilično jasnu sliku značajnog dijela hrvatskog nakladništva filmova na DVD-diskovima.

\subsection{Rezultati istraživanja}

\section{Intervjui s knjižničarima}

Poteškoće u radu vezanom uz filmske zbirke: knjižničari ističu da je bitan problem nedovoljno kvalitetna ponuda filmova na domaćem tržištu te da je prisutan trend objavljivanja manje kvalitetnih filmova. U knjižnici K5 ističu da se u Hrvatskoj može naći jako malo relevantnih filmskih naslova na DVD-u i da se

\footnotetext{
30 Menart. [citirano: 2017-09-17]. Dostupno na http://www.menart.hr.

31 Discovery. [citirano: 2017-09-17]. Dostupno na http://www.discoveryfilm.hr.

32 Restart label. [citirano: 2016-09-17]. Dostupno na http://www.restartlabel.net.

33 Blitz film \& video distribution također je nakladnik koji objavljuje dosta filmova na DVD-diskovima, no predstavnici tog nakladnika nisu pristali na sudjelovanje u istraživanju.

34 Evans, Edward G.; Margaret Zarnosky Saponaro. Nav. dj.; Wilson, Virginia. Nav. dj.
} 
sve manje objavljuju vrijedni filmovi. I u knjižnici K15 ističu da na tržištu nema dovoljno kvalitetnih filmova i da je svakom sljedećom nabavom sve teže izabrati dobar film. U knjižnici također ističu da je prije, dok su se filmovi objavljivali na VHS-videokasetama, bilo puno kvalitetnijih filmova nego što ih danas ima na DVD-u. Knjižničari u intervjuima često ukazuju i na stroge zahtjeve koje nakladnici postavljaju knjižnicama putem ugovora. Među tim je ograničenjima i zabrana projekcije filmova u knjižnici ili zabrana kupovine filmova u trgovinama, tj. preko posrednika. Jedno od ograničenja jest i zabrana izrade kopije filma za slučaj da se original ošteti. Kada se DVD-disk ošteti, ako film više nije na tržištu, tada knjižnice ne mogu ispuniti jednu od svojih najvažnijih uloga da trajno očuvaju nabavljena filmska djela. Narodne knjižnice nisu obvezne trajno čuvati filmove, ali bi bilo poželjno da najmanje jedna ili nekoliko većih narodnih knjižnica nastoji trajno čuvati filmove na DVD-diskovima jer će inače svi ti filmovi, ili barem većina, za nekoliko godina biti nedostupni.

Kvaliteta filmske zbirke u knjižnici: u knjižnici K1 nabavljaju klasična djela filmske umjetnosti. Naglašavaju da nedostupnost filmova ograničava mogućnosti izgradnje kvalitetnije zbirke. Cijena starih kvalitetnih filmova vrlo je povoljna - 15 ili 20 kuna - ali je velik problem to što na domaćem tržištu nema dovoljno tih filmova. Stoga ih ponekad nabavljaju iz inozemstva, bez prijevoda na hrvatski. Sasvim drugi tip filmova koji čine jaku stranu zbirke u istoj knjižnici jesu hitovi poput Transformera ili Nindža kornjača. Za njima je potražnja golema, pa se knjižnica mora tome prilagoditi. Kao jake strane svoje filmske ponude u knjižnici ističu upravo ta dva tipa filmova: vrlo popularne filmove i kvalitetne antologijske filmove. U knjižnici K8 također nastoje održati ravnotežu pri nabavi filmova. Godišnje nabavljaju $20 \%$ do $30 \%$ filmskih klasika, a ostatak nabave prati recentnu filmsku produkciju, za koju ističu da se dobro posuđuje. S obzirom na slabu ponudu filmova na domaćem tržištu, posebno starijih, antologijskih i neameričkih filmova, u većini knjižnica ističu da ne mogu nabaviti manje popularne naslove. U knjižnici K17 prostor za napredak svoje filmske zbirke vide u nabavi većeg broja manje popularnih filmova, no također ističu da se na domaćem tržištu ne može doći do takvih filmova. U knjižnici K5 ukazuju na problem dupliciranja zbirki u različitim knjižnicama jer sve uglavnom imaju komercijalne filmove koji prevladavaju na tržištu. Posebnost te knjižnice jest neposudbena zbirka antologijskih filmskih naslova koju koriste za knjižnične filmske projekcije. Knjižničar ističe da se filmove iz te zbirke može naći u većini filmskih enciklopedija, ali ne i na domaćem tržištu. Oni su dospjeli u knjižnicu donacijama stalnih korisnika koji su primijetili da nedostaju neki naslovi te su ih ponudili knjižnici. U knjižnici K6 filmska zbirka ima više od 4000 naslova. Smatraju da više ne mogu poboljšati zbirku iako imaju dovoljno financijskih sredstava da kupe sve vrijedne filmove na tržištu. Naime i oni problem vide u slaboj ponudi filmova. 
Načini nabave filmova za knjižnicu: knjižničari filmove najčešće nabavljaju izravno od filmskih nakladnika ili preko posrednika: u trgovinama i od trgovačkih putnika koji posjećuju knjižnicu. I u knjižnici K1 filmove najčešće nabavljaju od nakladnika, tj. distributera, kako ih često nazivaju u knjižnicama. Istaknut je problem da ima jako malo filmskih nakladnika: Continental, Blitz i Menart. U knjižnici ističu da se Continental gasi, da Blitz ne stoji dobro te da je sada naglasak na Menartu. S tim nakladnicima knjižnica ima ugovore koji reguliraju pravo posudbe filmova. Knjižnica također filmove istih nakladnika nabavlja u maloprodaji. Filmove se u knjižnici nabavlja i izravno od autora, naprimjer ako je neki naslov objavljen u manjoj nakladi, ali takav tip nabave puno je rjeđi. U gradu u kojem se nalazi knjižnica K2 nema većih maloprodajnih trgovina, pa filmove ne nabavljaju na taj način, osim preko kioska. I knjižnica K18 u malom je gradu bez trgovina s filmovima, pa ponekad knjižničari posjete trgovine u obližnjim većim gradovima. Glavni je način nabave filmova kupovina od nakladnika i trgovačkih putnika, a nabavljaju filmove i posjetom Mjesecu hrvatske knjige i sajmu Interliber. U knjižnici K14 filmove nabavljaju od većih nakladnika s kojima imaju ugovore, a filmove manjih nakladnika znaju kupiti izravno u trgovini jer s njima nemaju ugovore. U knjižnici K17 filmove nabavljaju od nakladnika, u maloprodaji ili od posrednika, tj. firme koja ima potpisane ugovore s nakladnicima te knjižnici šalje ponude i filmove za pregled prije kupovine. Za Šareni dućan u knjižnici ističu da je jedan od kvalitetnijih ponuđača filmova. Kod njih se, osim filmova s prijevodom, mogu naći i filmovi bez prijevoda. Knjižnica također manji broj neobičnijih filmskih naslova kupuje od distributera Eskadrila. Knjižnica gotovo nikad ne kupuje filmove izravno od autora. U knjižnici K16 filmove manjih nakladnika i stare filmove koje je teže naći, a za kojima postoji dosta potražnje, knjižničarka traži u internetskim trgovinama, naprimjer Stripovi.hr. Zanimljiv je slučaj knjižnice K5 u kojoj ističu da im korisnici samoinicijativno donose vrijedne antologijske filmove na DVD-diskovima, a koje knjižnica zatim čuva u internoj neposudbenoj zbirci. Knjižnica te filmove tretira kao fotokopije koje korisnicima mogu biti od izuzetne važnosti. Ti filmovi mogu se pogledati u knjižnici. Knjižničar smatra da treba čuvati i tako nabavljene filmove jer je važna svrha knjižnice obrazovanje.

Razina zadovoljstva ponudom filmova na domaćem tržištu: knjižničari u značajnom dijelu knjižnica uključenih u ovo istraživanje nisu zadovoljni ponudom filmova na domaćem tržištu te smatraju da se ona smanjuje kvantitativno i kvalitativno. Ukazuju na slabu ponudu sljedećih filmova: domaći filmovi, klasični igrani filmovi, dokumentarni filmovi, festivalski filmovi. U knjižnici K5 ističu da je teško nabaviti starije domaće filmove, ali se trude na sve načine, pa ih nabavljaju i na VHS-videokasetama. Ponekad im korisnici daruju starije domaće filmove na VHS-videokasetama, pa ih knjižnica prebaci na DVD kako bi upotpunila zbirku: 
„Recimo, hrvatski feljtonistički film ili nešto što je izdavao Zagreb film - te stvari nastojimo nabaviti po svaku cijenu. Čak i Zagreb film nekad zamolimo, ako oni imaju u svojoj zbirci nešto, da to kopiraju pa nam pošalju ako je moguće." (K5)

U toj knjižnici ne oklijevaju kontaktirati ni Hrvatsku radioteleviziju ako traže neki bitan film, ali pritom nailaze na financijsku zapreku jer HRT naplaćuje korištenje filmova iznosima koji su za knjižnicu veliki. U knjižnici smatraju da bi HRT prema zakonu trebao slati filmove u svojoj produkciji knjižnicama bez naknade. I u knjižnicama K13 i K16 ističu da situacija s nabavom domaćeg igranog filma nije dobra. U knjižnici K15 primijetili su da se dokumentarni i eksperimentalni filmovi u Hrvatskoj dosta snimaju, no ne vide te filmove u tržišnoj ponudi. I u knjižnici K6 nezadovoljni su ponudom hrvatskih filmova. Ističu da je malen broj igranih i dokumentarnih filmova objavljen na DVD-u. Obrazovne dokumentarne filmove nabavljali su od Zagreb filma, no korisnici nisu bili zadovoljni njihovom tehničkom kvalitetom. U knjižnici K1 ističu da u ponudi nedostaje dokumentarnih filmova, posebno domaćih. U knjižnici nisu zadovoljni ni ponudom antologijskih domaćih igranih filmova i serija:

„Ne možemo mi iznajmljivati seriju Velo misto ili Malo misto kad to ne postoji, to službeno nikad nije objavljeno. (...) Nažalost, takve naslove koji su dio filmske lektire ovdje, domaće, ne možemo imati. Eto, to je problem koji je nerješiv.“ (K1)

Na domaćem je tržištu također manjkava ponuda inozemnog filma jer su dostupni pretežno holivudski igrani filmovi. Naprimjer u knjižnici K2 voljeli bi da u ponudi ima više filmova koji nisu na engleskom jeziku. U knjižnici K6 ukazuju na to da se da se ponuda inozemnih filmova smanjuje te da ih nema dovoljno u ponudi, posebno igranih i dokumentarnih filmova. U knjižnici K13 ističu da nema puno azijskih filmova te da je manja ponuda europskog filma. Ne smatraju da se ponuda komercijalnih filmova smanjuje. I u knjižnici K15 ističu da je ponuda dobra što se tiče količine filmova, no da je kvaliteta ponuđenih filmova ispod razine prijašnjih vremena. Taj pad kvalitete započeo je u posljednje tri ili četiri godine. U knjižnici ukazuju na nedostatak antologijskih filmova te recentnih filmova $\mathrm{s}$ uglednih međunarodnih festivala, kao i novijih europskih filmova. Smatraju da se nakladnici vode isključivo gledanošću i potražnjom. No naglašavaju da široka potražnja često nije mjerodavan pokazatelj kvalitete. Ni u knjižnici K17 nisu zadovoljni ponudom filmova na domaćem tržištu. Za filmsku ponudu ističu da se smanjuje, da se objavljuju samo oni filmovi za koje su manje-više svi čuli, dobro reklamirani filmovi, dok se ne objavljuju filmovi za čiju proizvodnju i reklamu ne postoje jednaka financijska sredstva, a jednako su dobri, nekad čak i kvalitetniji. Zanimljivo je da čak ni antologijski holivudski filmovi nakladnicima nisu previše zanimljivi za objavljivanje. U knjižnici K5 govore da na domaćem tržištu nema 
temeljnih filmskih naslova koji su obilježili povijest filma poput filma Građanin Kane. U knjižnici K6 ukazuju na velik pad ponude filmova u odnosu na prethodne godine. U knjižnici $\mathrm{K} 1$ ističu da u zadnje vrijeme imaju veću mogućnost nabave europskog filma, iako ta ponuda nije ni blizu ponudi komercijalnih holivudskih filmova. U knjižnici K7 filmove nabavljaju tek godinu i pol dana. Ističu da su trenutačnom ponudom zadovoljni. Ta knjižnica odudara od većine knjižnica u istraživanju jer je tek nedavno počela s izgradnjom filmske zbirke. Očito je da se stanje na tržištu filmova sa stajališta relativno nedavno oblikovane filmske zbirke percipira drukčije nego sa stajališta knjižnica čije su filmske zbirke oblikovane nekoliko godina ranije, pa su puno bogatije filmovima i imaju veće potrebe za nabavom novih filmova. O snažnom utjecaju nakladnika na mogućnosti formiranja filmskih zbirki i situaciji vezanoj uz ponudu filmova na DVD-diskovima može se steći dojam iz izjave jednog od intervjuiranih knjižničara:

„Prvo ide nabava. Tu smo ograničeni utoliko što imamo četiri, odnosno pet distributera. Oni imaju svoje liste naslova i sve što mi možemo naručiti, to je unutar tih lista. Tako da, nažalost, ima cijeli niz klasičnih, vrhunskih filmova koje nemamo s hrvatskim titlovima." (K1)

Nabava stranih neprevedenih filmova iz inozemstva: ni u jednoj knjižnici ne nabavljaju filmove izravno u inozemstvu. Ni u knjižnici K5 ne nabavljaju filmove iz inozemstva, ali smatraju da će prije ili poslije morati poraditi na tome jer se kod nas objavljuju prvenstveno filmovi koji su najpopularniji kod publike. U istoj knjižnici ističu da je zbog računovodstvenih procedura inozemna nabava komplicirana. Računovodstvene, tj. zakonske procedure koje reguliraju nabavu filmova bitan su uzrok zbog kojeg knjižnice ne nabavljaju filmove iz inozemstva. U knjižnici K8 ističu da moraju poštovati zakone o nabavi te da je to jedan od čimbenika koji otežavaju nabavu građe iz inozemstva. Isti uzrok navodi se i u knjižnici K17, ali u njoj, kao i u nekim drugim knjižnicama, ipak imaju posredne metode nabave inozemne građe. Filmovi iz inozemstva nabavljaju se preko lokalnih knjižara koji knjižnici mogu ispostaviti svu zakonski potrebnu dokumentaciju. U knjižnici K1 imaju preko 300 neprevedenih filmova te ističu da postoji zanimanje za te filmove i da ima korisnika koji će ih posuditi kako bi učili jezik na kojem je film. U knjižnici K10 imaju veći broj neprevedenih filmova na engleskom jeziku. Ti se filmovi posuđuju bez obzira na nedostatak hrvatskog prijevoda. U knjižnici K6 ističu da imaju malo neprevedenih filmova jer smatraju da bi tek dio korisnika mogao gledati filmove na engleskom ili nekom drugom jeziku. Suprotno tomu, u knjižnici K17, u kojoj nemaju puno neprevedenih filmova, najviše 50, smatraju da filmovi s engleskim podnaslovima ne bi trebali biti problem velikom broju korisnika:

„Manje-više danas svi znaju engleski, tako da to nije nekakav preveliki problem, osobito za ljubitelje dobrog filma koji ciljano traže.“ (K17) 
Pogledajmo još dva primjera u kojima knjižničari imaju različite stavove o pitanju nabave filmova iz inozemstva. U knjižnici K15 imaju vrlo malo neprevedenih filmova, ali smatraju da bi nabavom filmova iz inozemstva mogli napraviti kvalitetniju filmsku zbirku. Kao mogući problem pri tom tipu nabave ukazuju na autorska prava, tj. postavlja se pitanje bi li filmovi nabavljeni u inozemstvu mogli biti posuđivani u knjižnici. S druge strane, u knjižnici K7 ne vide potrebu za nabavom filmova iz inozemstva jer smatraju da filmove koje korisnici traže domaći dobavljači više-manje uspijevaju dobiti u vrlo kratkom roku. Ovdje je važno istaknuti da je knjižnica $\mathrm{K} 7$ počela s nabavom filmova tek prije godinu i pol dana te da s obzirom na veličinu svoje zbirke (oko 800 naslova) još ima dovoljno vremena prije nego što se priključi knjižnicama koje imaju nekoliko tisuća naslova i u kojima više nema mogućnosti da se filmska zbirka izgrađuje zadovoljavajućim tempom i kvalitetom zbog ograničene ponude filmova na domaćem tržištu.

Knjižnice kao nakladnici filmova: jednim od pitanja u intervjuu istražilo se mišljenje knjižničara o tome trebaju li se (i mogu li se) knjižnice uključiti kao nakladnici u objavljivanje na DVD-diskovima određenih vrijednih domaćih i stranih filmova za čiju objavu komercijalni nakladnici nemaju interesa. Većina knjižničara smatra da bi to imalo smisla, ali ih prije svega brine je li to financijski moguće. U knjižnici K1 smatraju da bi se knjižnice trebale uključiti u objavljivanje vrijednih filmova na DVD-u ako je motiv promicanje kulture i ugled ustanove. U knjižnici K2 smatraju da je to dobra ideja, ali da bi problem kod objavljivanja filmova mogla biti autorska prava koja je složenije riješiti nego kod knjiga. U knjižnici K5 smatraju da je to izvrsna ideja, ali da bi to bili „,veliki investicijski zahvati za knjižnicu koja pokušava pokrpati sve rupe, pogotovo sad, u trenutku kad je kriza“. U knjižnici K6 imaju bogat izdavački program knjiga, a smatraju da ne bi bilo loše započeti i s objavljivanjem filmova. No također su zabrinuti zbog autorskih prava i trenutačnog stanja financija u Hrvatskoj. U knjižnici K11 smatraju da nemaju dovoljno financijskih sredstava ni za nabavu tiskane građe, a posebno ne za filmsku građu. U knjižnici K12 smatraju da u situaciji smanjivanja financijskih sredstva knjižnicama ne bi bilo u interesu odvajati sredstva za objavljivanje filmova. U knjižnici K15 mišljenja su da bi bilo dobro da knjižnica objavljuje filmove jer su oni vrijedna kulturna baština, kako domaća tako i strana, ali također misle da zbog financija to neće biti moguće.

\section{Intervjui s nakladnicima}

Broj novoobjavljenih filmskih naslova: u nakladničkoj kući Menart ističu da se posljednjih godina u Hrvatskoj smanjuje broj novoobjavljenih filmskih naslova. Oni nastoje objavljivati popularnije filmove velikih holivudskih studija, takozvanih majora kao što su Warner, Sony Pictures, Disney, Fox, MGM, Universal i 
Paramount. I nakladnik Restart ${ }^{35}$, udruga koja objavljuje isključivo dokumentarne filmove, iz godine u godinu smanjuje broj novoobjavljenih filmova, kao i naklade. Ističu da se u Hrvatskoj smanjuje broj novoobjavljenih filmskih naslova na DVD-diskovima:

„Objavljuju se ziher hitovi, direktno nakon kinodistribucije. I to se uglavnom radi o holivudskim naslovima i nešto jako sitno ovih art naslova, malo većih.“ (Menart)

Kao uzrok smanjenog objavljivanja filmova na DVD-u u Restartu navode širenje digitalne televizije, pojavu platformi Video on Demand kao što su MAXtv, VIP TV i B-net te veliku prisutnost piratizacije, tj. ilegalnog gledanja i preuzimanja filmova na internetu . Nakladnik Discovery također ističe da se smanjuje broj novoobjavljenih filmskih naslova na DVD-u zbog toga što gledatelji do filmova dolaze putem interneta te zbog platformi televizijskih programa Video on Demand. Zbog toga su u Discoveryu prije otprilike sedam mjeseci u potpunosti odustali od objavljivanja DVD-filmova.

Budućnost objavljivanja filmova na DVD-diskovima u Hrvatskoj: u Menartu ističu da će se novi filmski naslovi objavljivati dok god postoji zanimanje publike i dok god to bude profitabilan posao za maloprodaju. Ako neki od majora, tj. velikih holivudskih filmskih studija s kojima Menart surađuje, bude prezahtjevan sa svojim ugovornim obvezama, neće biti novih naslova tih tvrtki. U Restartu smatraju da se broj objavljenih filmskih naslova u Hrvatskoj sigurno neće povećavati najmanje sljedećih pet godina. Razmišljaju o objavljivanju ekskluzivnih DVD-izdanja s puno više dodatnih sadržaja. I u Discoveryu smatraju da se tržište filmova na DVD-diskovima neće oporaviti u sljedećih pet godina.

Objavljivanje stranih, neameričkih filmova: u Menartu ističu da velikom većinom, čak $99 \%$, objavljuju američke igrane i animirane filmove velikih holivudskih filmskih studija. Kao razlog slabe ponude neholivudskih filmova navode prilagođavanje onomu što publika traži, tj. objavljuju one filmove s kojima mogu zaraditi. U Restartu ističu da prvenstveno objavljuju europske dokumentarne filmove, ali objave također i američke neholivudske dokumentarne filmove ili dokumentarne filmove iz drugih dijelova svijeta. Ne vode se prostornim ograničenjima, već objavljuju filmove koji su kvalitetni. Kao uzrok manjem broju objavljenih domaćih filmova navode to što nema puno dobrih hrvatskih dugometražnih dokumentarnih filmova koji bi bili pogodni za objavljivanje na DVD-u. Također ističu da se hrvatski filmovi slabo gledaju, pa im se to ne bi isplatilo. U Discoveryu ističu da su prije većinom objavljivali igrane filmove, oko $95 \%$, a ostalo su bili dokumentarni i animirani filmovi. Objavljivali su većinom filmove koji nisu američki,

35 Restart je udruga unutar koje se nalazi odjel Restart Label, koji se bavi isključivo objavljivanjem dokumentarnih filmova na DVD-u. U tekstu ćemo upotrebljavati naziv Restart, a pritom mislimo na Restart Label, tj. nakladnički odjel unutar udruge Restart. 
posebno europske i azijske filmove. Objavili su jako malo hrvatskih filmova, tek desetak filmova u razdoblju od desetak godina. No Discovery je sada u potpunosti prestao s objavljivanjem filmova na DVD-diskovima.

Objavljivanje starijih antologijskih filmova: u Menartu ističu da su neki od tih filmova traženi, pa ih imaju u ponudi iako se radi uglavnom o starijim holivudskim filmovima. U Restartu ne objavljuju starije antologijske dokumentarne filmove:

„Razmišljali smo isto o nekim paketima, međutim jednostavno, kako je ta DVD-prodaja jako pala, onda smo se koncentrirali ustvari na novije stvari. (...) Međutim nije to isključeno kao opcija. Mi smo mala udruga i ustvari nemamo ni kapaciteta.“ (Restart)

U Discoveryu ističu da su objavljivali zanimljive naslove toga tipa, naprimjer filmove Akire Kurosawe, Luisa Buñuela, Alfreda Hitchcocka i Roberta Rosellinija.

Mogućnosti financijske podrške za objavljivanje filmova: u Menartu ne koriste nikakve potpore. U Restartu ističu da od hrvatskih državnih ustanova dobivaju određenu financijsku potporu od Hrvatskog audiovizualnog centra (dalje u tekstu HAVC) za objavljivanje domaćih filmova. HAVC svake godine raspisuje natječaj za poticanje komplementarnih djelatnosti. ${ }^{36}$ Ističu da su ta sredstva dovoljna za njihove planove objavljivanja DVD-a, ali da ne postoji državna potpora za promidžbu filmova, a što smatraju vrlo bitnim u današnjem dobu kada je konkurencija velika zbog interneta, piratizacije, VoD-platformi i, općenito, povećane kulturne ponude.

Suradnja s narodnim knjižnicama: u Menartu ističu da s knjižnicama jednim dijelom posluju izravno, a jednim dijelom preko partnerske tvrtke koja obilazi knjižnice te nudi katalog Menartovih izdanja - nove filmove, glazbu i knjige. U Menartu ističu da su prije nekoliko godina knjižnicama prodavali više filmova. U Restartu ističu da svako izdanje na DVD-u, prije nego što dođe u trgovine, prvo ponude knjižnicama. U 10 do 15 knjižnica Restart prodaje filmove izravno, a u ostalim knjižnicama prodaju filmove preko tvrtke Eskadrila. Oko 30 do 35 knjižnica u Hrvatskoj kupuje Restartove filmove. Najviše filmova prodavali su knjižnicama 2011. i 2012. godine. U Discoveryu su s knjižnicama poslovali izravno slanjem obavijesti o tome da je određeni film objavljen, nakon čega su ga knjižnice mogle naručiti. Ističu da u posljednjih godinu i pol dana nisu imali nijednu narudžbu iz knjižnica iako u ponudi imaju oko 700 prethodno objavljenih filmskih naslova.

Specifičnosti poslovanja s narodnim knjižnicama: u Menartu ističu da u početku poslovanja zbog piratizacije knjižnicama nisu odmah prodavali nove filmske naslove, ali da sada knjižnice nove naslove dobivaju odmah. U Restartu ističu

36 Hrvatski audiovizualni centar. Poticanje komplementarnih djelatnosti. [citirano: 2017-09-17]. Dostupno na http://www.havc.hr/o-nama/javni-pozivi/komplementarne-djelatnosti. 
da filmovi za knjižnice imaju nešto veću cijenu od maloprodajne jer ih knjižnice posuđuju, pa ih više ljudi vidi. S druge strane, Restart prvo nudi filmove knjižnicama, najmanje dva tjedna prije nego što se pojave u trgovinama. U Discoveryu ističu da je specifičnost poslovanja s knjižnicama bila u tome što one nisu imale sredstva za kupovinu u trenutku kad im je to odgovaralo, nego bi sredstva za nabavu filmova morale dobiti iz proračuna grada, općine ili županije.

Mogućnosti projiciranja filmova u knjižnici: u Menartu ne prodaju prava na javno prikazivanje filmova, već isključivo prava na posudbu filmova. U Restartu ističu da knjižnice od njih mogu kupiti i prava na javno prikazivanje. U tom slučaju Restart knjižnici šalje inačicu filma s boljom slikom kako bi projekcija bila kvalitetnija. Cijena filma za posudbu je oko 100 kuna, a za 150 kuna mogu se dobiti i prava na prikazivanje filma. Broj dopuštenih projekcija dogovara se između Restarta i knjižnice. U Discoveryu nisu prodavali prava na prikazivanje filmova u knjižnicama.

\subsection{Rasprava o rezultatima istraživanja}

U ovom dijelu teksta detaljnije ćemo razmotriti važne uvide do kojih smo došli intervjuiranjem knjižničara i filmskih nakladnika. Također, predložit ćemo i razmotriti aktivnosti koje mogu pridonijeti rješavanju poteškoća u radu s filmskim zbirkama pri unapređivanju filmskih zbirki i usluga te zadržavanju starih i privlačenju novih korisnika filmskih zbirki. Ta razmatranja i prijedlozi mogli bi potaknuti daljnja istraživanja i aktivnosti kojima se mogu unaprijediti filmske zbirke hrvatskih narodnih knjižnica.

\section{Pregled važnih uvida iz istraživanja}

Za dio knjižnica uključenih u istraživanje problem je nedostatak financijskih sredstava. Mnoge narodne knjižnice u Hrvatskoj stoga uopće nemaju filmske zbirke. Na nedostatak sredstava za nabavu filmova utječe i to što ni u jednom knjižničnom pravilniku ili zakonu nije određen minimalan financijski iznos namijenjen za tu svrhu. Stoga knjižničar zadužen za filmsku zbirku mora senzibilizirati voditelja knjižnice da se za filmove izdvoje određena financijska sredstva. Dakle iznos koji se izdvaja za filmsku zbirku ovisi o sklonostima voditelja knjižnice, što može biti problem, posebno kada je gospodarstvo u recesiji. Veličina mjesta u kojem se knjižnica nalazi i razvijenost gospodarstva u tome mjestu također imaju velik utjecaj na veličinu ukupnog proračuna knjižnice, pa tako i dijela proračuna izdvojenog za filmove.

Narodne knjižnice, osim obrazovne, informacijske i rekreativne uloge, imaju također ulogu dugotrajnog očuvanja dokumenata, a posebno onih dokumenata važnih za domaću i svjetsku kulturnu baštinu. U Hrvatskoj još ne postoji depozi- 
tarna knjižnica u koju bi se mogli slati filmovi za koje u knjižnici više nema mjesta. ${ }^{37}$ Knjižničari ističu da su DVD-diskovi na kojima su pohranjeni filmovi podložni čestim oštećenjima. Zamjena oštećenih DVD-diskova često je nemoguća jer na tržištu više nema dostupnih primjeraka tog filma. U intervjuima s nakladnicima doznali smo da oni nemaju financijski interes ponovno proizvoditi zamjenske filmove na DVD-diskovima u slučaju da neke knjižnice žele zamijeniti oštećene primjerke. Stoga bi bilo vrlo korisno da knjižnice imaju pouzdanu mogućnost zamjene oštećenih filmova. U dosta knjižnica spominju da ih ugovori s nakladnicima ograničavaju u korištenju nabavljenih filmova. Ako je u ugovorima definirano da knjižnica ne može napraviti rezervnu kopiju filma, a taj se film ne može više kupiti na tržištu, rezultat je to da će velik broj filmova, nakon što se ošteti DVD-disk, ostati trajno nedostupan korisnicima knjižnice.

U nekim knjižnicama istaknuto je da je bitna prepreka za izgradnju filmskih zbirki nedovoljno kvalitetna i nedovoljno raznolika ponuda filmova na tržištu, kao i to što se posljednjih godina smanjuje broj filmova u ponudi. Također, temeljni zaključak do kojeg smo došli na temelju intervjua s nakladnicima jest taj da situacija u nakladništvu znatno ograničava mogućnosti izgradnje raznolikih knjižničnih filmskih zbirki. Nakladnici u intervjuima ukazuju na to da se smanjuje broj filmova na tržištu na kojem preostaju ponajviše noviji holivudski igrani filmovi. S obzirom na ustanovljenu situaciju neraznolike ponude filmova na tržištu, pitanje je mogu li (i u kojoj mjeri) knjižnice pridonijeti izgradnji raznolikijih filmskih zbirki.

Dio intervjuiranih knjižničara smatra da bi zbog slabe domaće ponude filmova bilo dobro nabavljati više filmova iz inozemstva. Međutim trenutno nijedna narodna knjižnica uključena u istraživanje ne nabavlja filmove izravno iz inozemstva, već se filmovi nabavljaju od domaćih nakladnika i posrednika - velikom većinom nabavljaju se filmovi koji su objavljeni u Hrvatskoj i imaju prijevod.

Intervjuirani knjižničari većinom smatraju da je za knjižnicu vrlo važan broj posudbi filmova. To je jedan od razloga zbog kojih knjižničari mogu nastojati prije svega nabavljati filmove koji su popularni, bez obzira na njihovu filmsku, umjetničku ili obrazovnu vrijednost.

\section{Prijedlozi aktivnosti za unapređenje filmskih zbirki}

Na temelju provedenog istraživanja moguće je izložiti nekoliko ideja za poticanje onih aktivnosti u knjižnicama koje bi mogle pomoći, ako ne u rješavanju, onda barem u ublažavanju utvrđenih problema.

37 Takva knjižnica postoji naprimjer u Finskoj, gdje se zove Nacionalna depozitarna knjižnica (The National Repository Library). Vidi Ministry of Education and Culture, Finland. Quality recommendation for public libraries, 2011. Str. 16. [citirano: 2016-08-09]. Dostupno na http://www. minedu.fi/export/sites/default/OPM/Julkaisut/2011/liitteet/OKM35.pdf?lang=en. 
Jedna od aktivnosti za održavanje i unapređivanje raznolikih filmskih zbirki jest nabava filmova iz inozemstva. Ti neprevedeni filmovi mogu biti zanimljivi za knjižnične korisnike koji govore engleski ili druge strane jezike. Kao prepreku koja otežava nabavu filmova iz inozemstva knjižničari najviše navode zakone o nabavi i računovodstvo. Za tu se prepreku zasigurno može naći rješenje ako više knjižnica intenzivnije krene nabavljati filmove iz inozemstva te zajedno osmisle i predlože promjene propisa koji otežavaju inozemnu nabavu. Suradnja knjižnica može biti korisna i kod međusobne razmjene podataka o kvalitetnim inozemnim nakladnicima i ponuditeljima filmova te o iskustvima i procedurama inozemne nabave filmova. Jedna od zajedničkih aktivnosti koja može pomoći izgradnji raznolikijih i bogatijih filmskih zbirki jest da narodne knjižnice zainteresiranoj kulturnoj javnosti skrenu pažnju na nedostatak raznolikih filmova na domaćem tržištu te da knjižnice u međusobnoj suradnji i preko svojih udruženja nastoje utjecati na povećanje državne financijske potpore za objavljivanje raznolikih filmova.

Još jedna zajednička aktivnost za povećanje raznolikosti dostupnih filmova kojoj vrijedi posvetiti više pažnje jest da se knjižnice financijski i organizacijski udruže na projektima objavljivanja vrijednih filmskih djela na DVD-diskovima, filmova koji inače nikad ne bi ugledali svjetlo dana na domaćem tržištu. To se može učiniti kao teže ostvariva mogućnost s obzirom na manjak financija na koji upozorava dosta knjižnica, ali i s obzirom na to da hrvatske narodne knjižnice do sada nisu objavljivale filmove na DVD-u. No ta je aktivnost knjižnica ostvariva ako se uzmu u obzir napredak i dostupnost digitalnih tehnologija potrebnih za izradu DVD-diskova i drugi čimbenici, poput veličine mreže narodnih knjižnica. Zanimljiv je podatak koji je iznio jedan od intervjuiranih nakladnika. Spomenuo je da je kod objavljivanja pojedinog filma na DVD-disku najmanja isplativa naklada u rasponu od 200 do 300 primjeraka. U Hrvatskoj postoje 202 narodne knjižnice. ${ }^{38}$ To znači da bi se mogli pokriti svi troškovi (ili velik dio troškova) objave pojedinog filma od strane jedne ili više knjižnica ako se objavi 200 primjeraka tog filma i ako potom svaka narodna knjižnica kupi barem jedan primjerak. No zasigurno bi se mogao prodati još veći broj primjeraka jer veće knjižnice trebaju više primjeraka istog filma, a također se može očekivati potražnja za primjercima istog filma kada se postojeći primjerci oštete. S obzirom na to da postoji puno vrijednih domaćih filmova koji nikada nisu objavljeni na DVD-u, knjižnice se u dogovoru s autorima ili producentima tih filmova kao nakladnici mogu prijavljivati na HAVC-ov natječaj za potporu objavljivanja domaćih filmova te lobirati za to da se povećaju javne financijske potpore za objavljivanje vrijednih filmova. Bitan razlog zbog kojeg bi narodne knjižnice trebale razmisliti o preuzimanju uloge filmskog nakladnika jest ne samo to što je jedna od njihovih važnih uloga osigurati dostupnost raznolikim djelima iz svih razdoblja već i to što knjižnice

38 Nacionalna i sveučilišna knjižnica. Adresar narodnih knjižnica u RH za 2011. [citirano: 201709-17]. Dostupno na http://stari.nsk.hr/UserFiles/File/NK-adrese.pdf. 
tako mogu ojačati reputaciju aktivnih čuvara domaće i svjetske filmske baštine. Također, raznolikim filmskim zbirkama koje nema nijedna druga institucija mogu privući nove korisnike. Objavljivanjem filmova knjižnice mogu riješiti i problem otkupa autorskih prava za prikazivanje filmova u knjižnicama. Naime tek jedan od intervjuiranih nakladnika po pristupačnoj cijeni prodaje prava na prikazivanje dokumentarnih filmova. Ujedno, taj nakladnik spada u manje nakladnike. Druga dva velika nakladnika koje smo intervjuirali ne prodaju prava na projekciju filmova. Ako knjižnice objavljuju filmove na DVD-diskovima, one širom svijeta mogu tražiti nakladnike vrijednih filmova koji imaju pristupačnu politiku projekcije filmova u knjižnicama. To bi bio znatan dobitak za knjižnice jer na osnovi kvalitetnog programa filmskih projekcija mogu privući nove korisnike ili povećati zanimanje starih korisnika. Dodatna prednost za knjižnice koje same objavljuju vrijedne filmove jest to što mogu mijenjati oštećene filmove.

U intervjuima su mnogi knjižničari ukazali na nedostatak domaćih dokumentarnih filmova na tržištu, kao i na znatno zanimanje korisnika za takve filmove. Objavljivanje hrvatskih dokumentarnih filmova koristilo bi knjižnicama, njihovim korisnicima i autorima filmova. Objavljujući domaće dokumentarne filmove knjižnice korisnicima omogućuju da posude brojne filmove koji govore o društvu u kojem žive i koji se ne mogu nigdje pogledati. Također, preuzimanjem nekonvencionalnih uloga poput izgradnje i promidžbe zbirke domaćeg dokumentarnog filma ili sudjelovanjem u organiziranju filmskog festivala filmova objavljenih od strane knjižnica, one mogu povećati svijest članova zajednice u kojoj djeluju o svojim aktivnostima i raznolikoj ponudi filmova koje imaju te potaknuti upis novih članova.

Još jedna od mogućnosti za unapređivanje raznolikih filmskih zbirki jest suradnja knjižnica s ustanovama koje imaju bogate filmske arhive, naprimjer s HRT-om i Hrvatskom kinotekom. Ako se filmovi iz njihovih arhiva objave na DVD-diskovima, mogu se distribuirati u svim hrvatskim narodnim knjižnicama i tako promijeniti trenutnu nepovoljnu situaciju u kojoj je velika većina filmova u tim arhivima nedostupna javnosti. S tim je povezan problem na koji su pažnju skrenuli intervjuirani nakladnici, a to je činjenica da je u Hrvatskoj devastirana distributerska mreža. Upravo razgranata mreža narodnih knjižnica može osigurati da se u većim, ali i manjim mjestima u Hrvatskoj mogu posuditi i gledati vrijedni i raznoliki filmovi.

Naposljetku, važno je istaknuti da se ne može očekivati da će raznolika ponuda filmova u knjižnicama, čak i ako se poveća, automatski voditi povećanoj posudbi tih filmova od strane korisnika knjižnica. Za to su potrebne aktivnosti poticanja razvoja filmskih interesa korisnika knjižnica. Te aktivnosti može osmišljavati, inicirati i provoditi pojedina knjižnica, konzorcij knjižnica ili knjižnice u suradnji s drugim zainteresiranim pojedincima i institucijama koje žele širiti krug publike za vrijedne i raznolike filmove. 
Prilikom dodjele financijskih sredstava iz državnog proračuna trebalo bi voditi računa o ravnomjernoj raspodjeli sredstava knjižnicama - ako mjesto u kojem je knjižnica nema velik mjesni proračun za kulturu i knjižnicu, onda bi knjižnica trebala dobiti razmjerno više sredstava iz državnog proračuna nego što dobivaju knjižnice u bogatijim mjestima. Također, ono što bi moglo ujednačiti veličinu i raznolikost filmskih zbirki u knjižnicama jest definiranje nacionalnih i obvezujućih standarda o minimalnoj veličini i raznolikosti filmskih zbirki u svim narodnim knjižnicama. Trebalo bi nastojati ujednačiti filmsku ponudu knjižnica širom Hrvatske, tj. pokušati pružiti određenu minimalnu filmsku ponudu u svim knjižnicama, uključujući i one koje se nalaze u gospodarski manje razvijenim sredinama.

Također, bilo bi poželjno da barem jedna od većih hrvatskih narodnih knjižnica nabavlja više primjeraka filmova i da jedan primjerak ne daje u posudbu, već da ga arhivski čuva u knjižnici i da ga se jedino tamo može pogledati. Na taj će način za nekoliko desetljeća ostati sačuvani filmovi koji su se objavljivali u Hrvatskoj. To je posebno važno zato što hrvatske knjižnice koje prikupljaju obvezni primjerak knjiga nemaju obvezu prikupljati obvezni primjerak filmova objavljenih na DVD-diskovima.

Knjižnice bi trebale aktivnije sudjelovati u kreiranju ugovora s nakladnicima, $\mathrm{i}$ to tako da zaštite svoje temeljne interese. Naprimjer u pregovorima s nakladnicima treba pokušati osigurati pravo na izradu rezervnih kopija filmova. Također, važno je ugovorima u korist knjižnica regulirati i to da knjižnice imaju pravo prebaciti filmove s DVD-diskova na neki novi tip dokumenata kad se (i ako se) on pojavi. U vezi s time poučno je bilo iskustvo kada su knjižnice povukle filmove na VHS-videokasetama u spremišta ili ih otpisale iz fonda knjižnica jer je nova tehnologija pohrane filmova na DVD-diskovima učinila VHS-videokasete zastarjelim nosačima koje većina korisnika više ne traži. Međutim povlačenjem filmova na VHS-videokasetama mnogi od tih filmova trajno su nestali iz ponude jer nikad nisu objavljeni na DVD-diskovima na domaćem tržištu. Stoga bi knjižnice trebale nastojati da u ugovorima s nakladnicima osiguraju pravo na to da sve kupljene filmove prebace na nove tipove medija kada se oni pojave na tržištu. U suprotnom, neće moći ostvariti jedan od svojih temeljnih ciljeva - dugoročno osiguravanje pristupa vrijednim filmskim djelima.

\section{Zaključak}

U radu je istražena jedna dosad nedovoljno istraživana tema iz polja knjižničarstva, a to je izgradnja raznolikih filmskih zbirki. Uvidi iz istraživanja upućuju na to da je jedna od najbitnijih poteškoća u izgradnji filmskih zbirki u hrvatskim narodnim knjižnicama nedostatak raznolikih filmova objavljenih na DVD-diskovima. To je pitanje u radu detaljnije istraženo te su na temelju uvida iz istraživanja 
predložene i neke od mogućih aktivnosti za ublažavanje tog problema. Neke od tih predloženih aktivnosti, poput one da knjižnice započnu objavljivati vrijedne filmove na DVD-diskovima, zasigurno su nekonvencionalne i mogu se činiti teže ostvarivima. No ako se uzmu u obzir različite okolnosti poput nedostatka raznolikih filmova na tržištu, nezainteresiranosti i nemogućnosti nakladnika da objavljuju raznolike filmove, razvoja digitalnih tehnologija koje omogućuju jednostavniju i puno povoljniju izradu DVD-diskova s filmovima, razgranatost i veličinu mreže hrvatskih narodnih knjižnica, mogućnosti suradnje narodnih knjižnica te njihovu misiju da osiguravaju dostupnost ideja i širenja znanja i kulture, onda se aktivnost objavljivanja filmova na DVD-diskovima od strane knjižnica ne čini nepotrebnom ni posve neostvarivom. Nadamo se da ta i ostale aktivnosti predložene u ovome radu mogu doprinijeti razmišljanjima i raspravi o tome kako izgraditi raznolike zbirke filmova.

\section{LITERATURA}

ALA. The freedom to view statement, 1989. [citirano: 2017-09-17]. Dostupno na http:// www.ala.org/vrt/professionalresources/vrtresources/freedomtoview

ALA. Intellectual Freedom Committee Subcommittee on the Impact of Media Concentration on Libraries. Fostering media diversity in libraries - strategies and actions. // Intellectual Freedom Manual. Chicago : American Library Association, 2010. [citirano: 2017-09-17]. Dostupno na http://courseweb.ischool.illinois.edu/ katewill/maybe/ala\%202010\%20intellectual\%20freedom\%20manual\%20eighth\%20edition.pdf

Aparac, Tatjana. Biti bibliotekar: jučer, danas, sutra. // Knjižnica: glasilo Zveze bibliotekarskih društev Slovenije 41, 2(1997), 33-44.

Buckland, Michael K. Five grand challenges for library research. // Library Trends 51, 4(2003), 675-686.

Buschman, John. On libraries and the public sphere. // Library Philosophy and Practice 7, 2(2005), 1-8.

Dilevko, Juris; Kalina Grewal. New approach to collection bias in academic libraries: the extent of corporate control in journal holdings. // Library \& Information Science Research 19, 4(1997), 359-385.

Dilevko, Juris; Alison Hayman. Collection development patterns of fiction titles in public libraries: the place of independent and small presses. // Library \& Information Science Research 22, 1(2000), 35-59.

Dilevko, Juris An alternative vision of librarianship: James Danky and the sociocultural politics of collection development. // Library Trends 56, 3(2008), 678-704. 
Discovery. [citirano: 2017-09-17]. Dostupno na http://www.discoveryfilm.hr

Duić, Mirko Filmske zbirke u hrvatskim narodnim knjižnicama. Doktorska disertacija. Zadar : Sveučilište u Zadru, 2015.

Evans, Edward G.; Margaret Zarnosky Saponaro. Developing library and information center collections. Westport, Conn. : Libraries Unlimited, 2005.

Grant, Carl. Value-added librarianship: creating it in our services and in the infrastructure upon which we rely. // Public Library Quarterly 32, 1(2013), 21-32.

Habermas, Jürgen. The postnational constellation: Political essays. Cambridge, MA : MIT Press, 2001.

Hansson, Joacim. Chantal Mouffe's theory of agonistic pluralism and its relevance for library and information science research. // Critical theory in library and information science: Exploring the social from across the disciplines / ed. by John. E. Buschman, Lisa M. Given and Gloria J. Leckie. Santa Barbara, Calif. : ABC-CLIO, 2010. Str. 249-257.

Hrvatski audiovizualni centar. Poticanje komplementarnih djelatnosti. [citirano: 201709-17]. Dostupno na http://www.havc.hr/o-nama/javni-pozivi/komplementarne-djelatnosti

IFLA. Smjernice za audiovizualnu i multimedijsku građu u knjižnicama i drugim ustanovama, 2005. [citirano: 2017-09-17]. Dostupno na http://archive.ifla.org/VII/s35/ pubs/avm-guidelines04-hr.pdf

Kranich, Nancy. A question of balance: the role of libraries in providing alternatives to the mainstream media. // Collection Building 19, 3(2000), 85-91.

Lilburn, Jeff. Too much "official" truth? Mainstream media, the alternative Press and the construction of common knowledge. SIMILE: Studies in Media \& Information Literacy Education 5, 4(2005), 1-10.

Lojo, Kemal. Bibliotekarstvo između profesionalizacije i ideologizacije. // ICSL Godišnjak, 6-7(2011), 193-206.

Majcen, Vjekoslav.; Hrvoje Turković. Kinematografija u Hrvatskoj - izvještaj o stanju. // Hrvatski filmski ljetopis 7, 27(2001), 53-95.

McDonald, Peter. Corporate inroads \& librarianship: the fight for the soul of the profession in the new millenium. // Progressive Librarian, 12-13(1997), 33-44.

Menart. [citirano: 2017-09-17]. Dostupno na http://www.menart.hr

Ministarstvo kulture. Javni poziv za dodjelu potpora za izdavanje knjiga u 2014. godini. [citirano:2017-09-17]. Dostupno na http://www.min-kulture.hr/userdocsimages/ Natjecaji/natje \%C4\%8Daj\%20programa\%20knji\%C5\%BEevne,\%20nakladni\%C4\%8Dke\%20i\%20knji\%C5\%BEarske/Upute_potpore_dopunjeno\%20(2)_LEKT. pdf 
Ministry of Education and Culture, Finland. Quality recommendation for public libraries, 2011. Str. 16. [citirano: 2016-08-09]. Dostupno na http://www.minedu.fi/ export/sites/default/OPM/Julkaisut/2011/liitteet/OKM35.pdf?lang=en

Nacionalna i sveučilišna knjižnica. Adresar narodnih knjižnica u RH za 2011. [citirano: 2017-09-17]. Dostupno na http://stari.nsk.hr/UserFiles/File/NK-adrese.pdf

Pavičić, Jurica. Po hrvatski film u Trst. // Hrvatski filmski ljetopis 5, 17 (1999), 41-46.

Restart label. [citirano: 2017-09-17]. Dostupno na http://www.restartlabel.net

Schmidt, Karen Past perfect, future tense: a survey of issues in collection development. // Library Collections, Acquisitions, \& Technical Services 28, 4(2004), 360-372.

Thussu, Kishan Daya. News as entertainment: the rise of global infotainment. Thousand Oaks, Calif. : Sage, 2007.

Wheeler, Joseph L.; Herbert Goldhor. Practical administration of public libraries. New York: Harper \& Row, 1966.

Wilson, Virginia. Research methods: interviews. // Evidence Based Library and Information Practice 7, 2 (2012), 96-97. 